\title{
Under-Valorization of Tragedies at the Borders of Europe: African Migrant Youth and the Politicization of Biological Pigmentation
}

\author{
Michael 0. Nwalutu1, Felicia I. Nwalutu², Eucharia U. Ngene ${ }^{3}$ \\ ${ }^{1}$ Social Justice Education, OISE, University of Toronto, Toronto, Canada \\ ${ }^{2}$ Department of History, University of Toronto, Toronto, Canada \\ ${ }^{3}$ National Engineering Design and Development Institute (NEDDI), Nnewi, Nigeria \\ Email:nwalutu@yahoo.co.uk
}

How to cite this paper: Nwalutu, M. O., Nwalutu, F. I., \& Ngene, E. U. (2018). Under-Valorization of Tragedies at the Borders of Europe: African Migrant Youth and the Politicization of Biological Pigmentation. Sociology Mind, 8, 1-20.

https://doi.org/10.4236/sm.2018.81001

Received: November 27, 2017

Accepted: December 16, 2017

Published: December 19, 2017

Copyright (c) 2018 by authors and Scientific Research Publishing Inc. This work is licensed under the Creative Commons Attribution International License (CC BY 4.0).

http://creativecommons.org/licenses/by/4.0/

\section{(c) (i) Open Access}

\begin{abstract}
As an emerging trend, young adults are crossing transnational borders as independent migrants. In this paper we use data collected with Interpretative Phenomenological Analysis, IPA in a qualitative field study conducted in 2013 in the Republic of Malta to examine the persistent restrictions imposed on African migrant youth at European borders. The analysis employs anti-racist and anticolonial theories to accentuate the border dynamics and EU policy imperatives that have driven migrant African youth into more hazardous measures to reach their destination. This paper becomes timely as the attention of international community is in the recent times drawn to a pervasive trend in transnational migration we have been grappling with for some time. Fed by the internal displacement of peoples in the Middle-East, Asia, and particularly the ongoing war in Syria, large number of migrants are ferrying across Mediterranean Sea to the borders of Europe. Before now, a majority of the casualties of the Africa-Europe migration are men, women, and children-dark-skinned Africans-whose lifeless bodies continued to wash up on the European coasts with none batting an eyelid. The questions that emerge are: what changed? We argue that politicization of biological pigmentation happens at the spaces of transnational border representation in which racialized African youth migrants are unfairly restricted. We conclude by proffering non-discriminatory approaches for managing the 21 st century youth migration.
\end{abstract}

\section{Keywords}

Transnational-Border, Migration, African-Youth, Clandestine, Casualties, European-Union 


\section{Introduction}

As an emerging trend, young adults are crossing transnational borders in large numbers as independent migrants, mostly from developing economies of the South to the industrialized countries of the North (Heidbrink, 2012). African youth have been part of this trend (Brachet, 2012), and in this context youth from the East, Central, and mostly West African countries constitute a larger segment of the Europe-bound migrant demography. The unrelenting surge in emigration of African youth as independent transnational migrants and the plight accompanying them en-route to Europe necessitated this paper. In the first nine months of 2013, more than 40,000 migrants arrived in Italy and Malta from Africa (Deutsche Welle, 2014). And there is a general lack of awareness on the working and living conditions of youth migrants (Wong, 2009). Internal displacement of peoples by natural and human-made disasters in almost all the continents implies that affected individuals migrate to Oversea-countries where they hope to find survival opportunities that are nonexistent and often elusive in their home countries (Ki-mon, 2009; Simms, 2009). Presently unimaginable batches of migrants arrive at the ports of Europe aboard fleets of non-sea-worthy boats laden with youth, children, and some adults (people from Africa, the Middle-East, and Asia), and now buoyed by the protracted war in Syria, large number of Arab migrants are also ferrying across Mediterranean Sea to the borders of Europe. The ongoing reports of thousands of drowning cases in the Mediterranean are indicators that the movement is not without devastating but avoidable consequences. Over 50,000 refugees drowned in the Mediterranean in the last 20 years (Deutsche Welle, 2014). Nothing is reported about death of migrants on transit (in the Sahara desert). There is urgent need to protect young migrants and ensure that migration leads to their development and those of their home and host countries (Deutsche Welle, 2014). Until now, most casualties of this movement were dark-skinned Africans whose lifeless bodies washed-up in large numbers at the coasts of Europe with no significant, conscientious and sustained effort by the EU states to attend to the root causes of the migration and offer meaningful support to the youth.

In this paper we used data collected with Interpretative Phenomenological Analysis, IPA in a qualitative field study conducted in 2013 in the Republic of Malta to examine the persistent restrictions on African migrant youth at the borders of Europe. The use of IPA stems from its focus on establishing how people make sense of what is happening to them. And considering the uniqueness of the participants in the study, it also encourages the researcher to meet and interview the participant in the latter's choice of location. It advances the understanding of global youth migration from anti-colonial and anti-racist perspectives in order to disturb extant EU immigration policies and praxis that have not only consistently read the skin pigments of young migrant Africans differently, but continues through practices of racism to thwart their efforts to reach mainland Europe (Pisani, 2012). The anti-immigrant strategies leave these 
youth with none but more tragic options in efforts to reach their destinations. The lucky among the African youth migrants who overcome the lethal rages of Sahara Desert and Mediterranean Sea have their dreams of ever reaching the Fortress Europe foiled through quasi-humanitarian efforts of EU border authorities who would round them up in a decoy of rescue mission. The rescued migrants are finger-printed, detained for almost two years, and then released with no travel document while some of them are summarily deported. We are thus compelled by these experiences to explore in this work the flagrant violation of migrant African youth's rights by the EU states' border officials. As African immigrants ourselves we write from a perspective of epistemic saliency, that is, from the authenticity of one's own experiences and voice (Dei, 2011). In other words, a space that allows a local subject to speak of her/his informed knowledge-base as distinct from being spoken for. By so doing we hope to draw attention to the duplicitous role of the EU states in the politicization of biological pigmentation at its borders with respect to its dealing with the African youth. The restrictive practice of EU border authorities has dire consequences for African migrant youth. It has resulted in drowning deaths of these mostly indigent and desperate migrants-they are left with one option-that of exploring the hazardous modes of reaching their destinations (Sassen, 2003). Therefore the sudden arousal of Europe to the plights of Syrian migrants on the Mediterranean who are fleeing unrests and insecurities in the Middle-East, as conceivably commendable as it might seem, also raises critical concerns around issues of racism at the borders of Europe. The questions that will guide the thrust of this work are: Why is the language of migrant representation in the EU switching from illegal, clandestine, and aliens to refugee and asylum seekers? Why is the politics of border restriction replaced with notions of migrants' reception and resettlement? In this paper therefore our working assumption is that politicization of biological pigmentation happens at the spaces of EU transnational border securitization.

\section{Review of Literature}

The persistence of neo-colonial schemes in developing economies has continued to insidiously conflate with the political and economic policies and practices of the industrialized North to perpetuate disruptions in the developing South (Simms, 2009; Chomsky, 2006; Willinsky, 1998). These chains of engagements and reactions constitute citizens previously settled and peaceful into stateless forced migrants (Baxter, 2008; Chua, 2003; Nwalutu, 2014). And the forcefully displaced migrants, in this context, youth from the global South who migrate to industrialized nations for protection and better life are impelled by border restrictions to make alternate migration choices, which are often very hazardous mode of migration (Sassen, 2003). They face enormous restrictive rules designed to check their entry into receiving societies. There is therefore an emerging concern on the impact of the heightened securitization of borders and intensifica- 
tion of selective migrant surveillance on the cultures of economic and political migration in countries of the industrialized North, specifically the EU states as it affects African migrant youth.

\subsection{Double Fortification at the Boarders of EU Member States}

The European parliament and European Council operationalized a draft to establish a new fortification that is based on distance surveillance with advanced technologies. The EUROSUR was formed to among other goals, use technological devices such as satellite imagery and drones to monitor the Mediterranean Sea and North African coasts. Its terms of reference was directed to pay priority attention to EU member states, persons in distress at sea, children, asylum seekers and victims of human trafficking, as well as person(s) in need of medical attention. All these are in line with the UN provision to safeguard human rights at the international waters (Frenzen, 2014; Newland, 2003; Phillips, 2014). An analysis of EU Regulations for FRONTEX's (EU boarder policing agent), coordinated surveillance of external sea borders was also foremost in the agenda, and the priority was aimed at enhancing protection (at least in writing) of migrants who must be intercepted or rescued. Interestingly, such a cogent and extremely critical document permits of many obvious technical lapses that enable state agencies of EU and its member states wash their hands off any blames when migrants related tragedies occur on EU territorial waters or areas within its jurisdiction. One of the loopholes is the regulation's obvious blankness on situations migrants are intercepted in territorial waters of a third state (non-member state of EU), which is what North African coastal states represent, which actually raises concern over push-back against the migrants. An observation was that prior to Libyan revolution for instance, Italy extended its borders to Libyan coasts by proxy. This implied that its boarder agents patrolled Libyan coasts with the sole aim of intercepting and disembarking migrant boats carrying Africans, since Libya is one of the coasts of departure for migrants from Africa (Frenzen, 2014; Newland, 2003). Today the demographic constituents of migrants crossing the Mediterranean Sea to Europe are buoyed by war in Syria, Middle East unrests, and displacements in parts of Asia. Mediterranean migrants today include Arabs, Asians and Eastern Europeans, and despite the escalation of anti-West terrorists attacks by Islamic fundamentalists EU has adopted an open-border and immigrant assimilation policies instead of the initial detention and deportation of largely African youth who were escaping the continent for obviously similar reasons as their Arabian, Asian, and middle Eastern contemporaries. It is in the light of these developments that this contribution continues to ask if Skin Color is a factor on how African youth migrants are treated at the borders of Europe. In 2009, Italy intercepted migrant boats with individuals in distress over Italian coast territorial waters, and instead of rescuing them, deported all the occupants back to Libya, not considerate of the implication of such a drastic action for the various categories of migrants on board the boat (Frenzen, 2014; Sunderland, 2012). This push-back strategy did not forestall the trip of subse- 
quent migrant boats, but it further raised the death toll of hapless African migrants including women and children.

The EU regulations for FRONTEX also prescribed that boats intercepted in the territorial sea or contiguous zone of any EU member state should be disembarked in same territory. This specific regulation provided a condition that allows authorities to still order an alteration of course of migrant boats that have made it into EU waters. This action is in flagrant violation of not just the fundamental right of the migrants but the International Refugee laws and International Maritime laws that demand that member states who are signatories to the regulations should under the circumstance discussed above, use all available means to identify intercepted persons so as to afford migrants opportunity to assert a non-refoulement claim (Sunderland, 2012). The aggressively heightened anti-immigrant operations of FRONTEX beyond EU territories informed therefore a paradox that requires closer details-for at the auspices of FRONTEX many more migrants death are recorded in the Mediterranean Sea (Sunderland, 2012). For instance, during the 2011 Libyan revolution that ousted Col. Gadhafi, FRONTEX sent its joint operations consisting of ships and aerial surveillance systems to Libya as back-up for Italy in order to frustrate influx of migrants from Africa. The North Atlantic Treaty Organization, NATO also deployed 21 ships at the Mediterranean as a tactical bid to foil arms supply to Gadhafi regime (Sunderland, 2012). The intensification of Libyan crisis, expectedly, drove an ethnically mixed-multitude of immigrants in Libya to the sea. These ethnically mixed groups of immigrants were escaping the onslaught of the Libyan dictator, Gadhafi but the incident that follows would begin to unsettle the humanitarian angle of EU's, NATO's, UNHCR's and IOM's operations on the Mediterranean Sea. While dallying over whose responsibility it was to rescue the boat conveying a batch of migrants out of Libya, the West watched 63 of them including 20 women and 2 babies die in the infamous "left to die" case (Heller, Pezzani, \& Situ Studio, 2012: 9; Strik, 2012). As a fall out of the war in Libya and Gadhafi's demise, many migrant refugee/asylum camps in Libya are at the moment, almost turned daily to modern slave market by the various Islamic fundamentalist groups, who were the offshoots of the war. Hence more and more desperate African youth are headed out to the open sea for Europe despite reports of baleful nature of the Mediterranean crossing.

This case accentuates the paradoxical outcome of deceptive propagation of international orders, which becomes a violation, legal and binding when and only when racialized and marginalized subject from developing economies are not the victims. The 1979 International Convention on Maritime Search and Rescue (SAR Convention) enjoins governments and all stakeholders to: “... ensure that assistance be provided to any person in distress at sea... regardless of the nationality or status of such a person or the circumstances in which that person is found" (ICMSAR, Chapter 2.1.10). The 1982 United Nations Convention on the Law of the Sea (UNCLOS, Art. 98: 2) also passes a responsibility on 
every coastal state party to: “...promote the establishment, operation and maintenance of an adequate and effective search and rescue service regarding safety on and over the sea and, where circumstances so require, by way of mutual regional arrangements co-operate with neighboring States for this purpose" (Heller, Pezzani \& Situ Studio, 2012: 10). This travesty of humanitarian work quickly strikes a chord with the apparently tactless, astute but revealing response of $\mathrm{Mr}$. Valeri Artemienko during the court case in 1992 in France, indicting him and his crew for murdering 8 African young migrant stowaways. Artemienko, before his life-jail sentence testified, to the embarrassment of the duplicitous Europe: "Europe will thank us for what we did" (Davies, 1995). In a yet emotionally charged testimony of Ukrainian sea Captain, Alexander Vinnisk, that exposes the dilemma the European border-policies subject her border-authorities, a process that impelled the crew into the murderous rage to slaughter the West African youth.

The question remains, who actually should be held responsible for incidents like this and many more that go unnoticed? The EU carrier-liability law with a fine of $£ 75.7$ million (Davies, 1995), which aims to cripple the fiscal base of ship owners caught wittingly or otherwise, conveying irregular migrants to Europe, thus became the death warrant for crews to cast overboard any irregular migrant they discover in their vessel. In 1985 the United Nations High Commission for Refugees was moved by instances such as the Vietnamese refugees case that happened earlier to put in place a number of emergency measures, which included providing to reimburse owners of vessels for cost incurred during sea-rescue exercise. The UNHCR provision also includes, to publicly commend the gestures of seafarers who rescue migrants (Sunderland, 2012). The tradition of sea faring has similar outstanding codes of which is to respond to migrants' distress calls (see Appendix for research questions, see also Strik, 2012; International Convention for the Safety of Life at Sea, 1974).

\subsection{Commitment to Transnational Migration Laws: EU and the Perils of African Migrant Youth}

The area of interest at this juncture is the conflicting intersection between domestic policies and maritime laws of the receiving states and international refugee law. For instance ship crews are under obligation to rescue sea migrants who run into distressful conditions, but they also have to transfer the rescued individuals to the nearest safe haven to save cost for themselves as well as in compliance with the provisions of the laws. States are however under no obligation to accept rescued persons because if there are refugees among the rescued individuals, the host country might be violating the law by repatriating them to their countries of origin. The question however is, has there been reduction in cases of migration into European borders via the sea or more specifically, are we foreseeing any reduction in the flow of migration of African youth to Europe? The view of this work is that the root cause of youth migration must be addressed if 
the phenomenon would be minimized or eradicated. Tackling the current surge in African youth migration to Europe would not be achieved through the policies and practices of border restriction and migrant management as is presently the case. The various states of origin (mostly developing countries) must be involved in the study geared towards understanding the drives of youth migration, bearing in mind that one size fits all strategy might not always work particularly when it comes to youth migration. Besides, the understanding that migrants are either political or economic refugees, which led Bjarnesen (2014) to reason that labor migrants and refugees are intertwined also brought about the notion of mixed migration. But as Phillips (2014) argues, migration evokes a polarized atmosphere of competition between immigrants and the citizens of a host country. The implication is that, among mixed migrants in a rescued boat, refugees and asylum seekers would be predisposed to receive more empathy from the citizens than do economic immigrants. For migration stakeholders and policy makers, there is however a need to tease out the distinct categories of youth migrants so as to properly analyze, and make provisions that might be tailored to and expedient for each group's needs.

\section{Methodology}

Interpretative phenomenological analysis (IPA) is employed in the qualitative field study that generated data for this work. The study aims to enhance the understanding of migrant Nigerian youth's experiences in Malta, Europe. IPA uses in-depth qualitative analysis, which is its major uniqueness, as distinct from psychology. Both psychology and IPA agree on a common goal-that of establishing how people think (make sense) of what is happening to them-differing only on how the thinking can best be investigated. IPA as an analytical methodology provides an avenue into various trajectories of qualitative data interpretation and analysis. As a methodology, IPA requires a small sample because it involves a detailed portrayal of the perceptions and understanding of the individual respondents in the interview. It implies that a long time is also required to analyze individual transcripts. It does not mean, however, that IPA is opposed to generalization of research findings to a larger population. It focuses on doing a painstaking analysis of the context. The near homogeneity of the population of study absolved of the stress of striving for a random sampling, and we alternatively engaged purposive sampling on a homogenous group of people. The samples were drawn from a demographic unit comprising Nigerian youth in Malta who shared a similar socio-economic status. The use of IPA in the processes of data collection and analysis, equips us to extrapolate without losing validity, the outcome to African and by further extension, global features of youth transnational movement. The research was anchored therefore on theoretical rather than empirical generalizability (Smith \& Osborn, 2007); and with the commitment to the IPA foremost requirements-that of understanding and giving needed voice to the claims and apprehensions of our interviewees as well as 
contextualizing and making sense of these concerns through a psychological lens (Larkin, Watts, \& Clifton, 2006; Shea, 2012). We will not hesitate to state that mere extraction of information from the Nigerian youth participants and other immigrants in Malta who are the target population of this study would be both insufficient and inappropriate if it failed to highlight the peculiarities and complexities of the current African youth movement and efforts by scholars to proffer approaches for its investigation. This is because the narratives of the youth migrants would essentially flow from their countries of origin, through transnational borders, to their present transit space or destination. This informs the need to understand migrants' holistic experiences right from the contexts of their environments of origin and follow through to the receiving societies. IPA as an analytical methodology provides us an avenue into various trajectories of qualitative data interpretation and analysis. As a methodology, IPA requires a small sample because it involves a detailed portrayal of the perceptions and understanding of the individual respondents in the interview. It does not mean, however, that IPA is opposed to generalization of research findings to a larger population. It focuses on doing a painstaking analysis rather than generalizing the outcome of the study.

The major assumption in interpretative phenomenological analysis is that the analyst is interested in learning something about the participant's psychological and sociological world. That may be in the form of constructs, perceptions, and beliefs that are reflected or suggested in the participant's responses. In other words, meaning (its context and complexities) is the central key to understanding the participant's world. We therefore engaged the text and interpretation process effectively to uncover the masked and layered meanings implied in participants' responses, which in itself is the light into their mental and social world (Smith \& Osborn, 2007). One of the goals of this paper is to prepare grounds for possible policy modifications at the sending nations, transnational borders, and receiving countries, in response to the current surge in youth transnational migration.

\subsection{Demographic Details}

In the field study, which was conducted in 2013 in the Republic of Malta, thirty four interviewees in all participated, and 34 field interviews were conducted along with six focus-group meetings. Twenty-eight migrant youth and six Maltese were interviewed in the study. Of the six Maltese youth, two were female and four were male. Of the 28 migrant youth, four were Filipino youth migrants (two were female and two male). The decision to recruit Filipino youth migrants was rather an alternative to the original choice of youth migrants from the other European states. This decision was informed by the realization upon arrival in Malta that citizens of European Union member states are treated to some degree as equal to the Maltese citizen. The decision to interview citizens of other European states who immigrated into Malta was to have a basis for triangulation and 
to substantiate information from the migration experiences of Nigerian youth. This purpose would be defeated if as citizens of one economic community (European Union) immigrant youth of other European states share, to some degree, the same level of rights and privileges as the Maltese. To account for this shortcoming Filipino immigrant youth who, like African migrants were classified by Maltese as 'third citizens' were recruited instead. The term third here does not necessarily imply that these youth were from the third world or a developing country, but again, Maltese citizenship could be better understood with the illustration of three-tier concentric circles. At the center or the first circle were the bona fide Maltese citizens, who were citizens by birth. The second tier of the circle is the position of non-Maltese who were certified citizens of the European Union, EU member states. Individuals who were neither Maltese citizens nor those of any of the member countries of the European Union were located at the outermost circle, and these were the third citizens. Interview sources disclosed that this became the case after Malta joined the EU on May 1, 2004.

\subsection{Synopsis of Findings}

Few of the participants' narratives relevant to this paper will be taken into account for the purpose of analysis. Based on the interviews, foremost in the findings was that the main factor driving Nigerian youth to migrate in large numbers is social insecurity and hopelessness. Other factors are displacement and force-migration, education, family reunion, unemployment, poverty, and influence of peer group. Majority of the youth migrants interviewed arrived in Malta in improvised non-sea-worthy boats; most of the youth migrants were also classified as asylum or refugee status migrants because their mode of immigration into Europe was deemed irregular. Only five of the interviewees from Africa possessed university degrees or college diplomas as opposed to all the Filipino migrants, who, although they possessed degree qualifications in their professions (largely, the health sub-sector), were trained and certified by their home government to undertake menial jobs positions like cleaner, nanny, house-help, hotel or restaurant attendant, before being recruited to leave their country for Europe. Of the four African youth migrants with degrees, only one received this qualification from home university before migrating to Libya and subsequently to Malta. Two gained their degrees at the University of Malta by migrating to join family members; one of them came specifically to study in Malta. He thereafter married a Maltese and settled in the country. It was gleaned from responses that youth from South-Eastern and Mid-Western Nigeria constitute the largest number of Nigerian youth migrants in Malta. Nearly half of the interviewed youth (10 interviewees), representing 41.7\%, are of the South-Eastern and Mid-Western origin. Six migrants each from the South-West and South-South, representing 25\% respectively, were interviewed, while two youth from the North-Central zone, representing $8.3 \%$, were interviewed. There were no Europe-bound youth migrants from the North-East and North-West 
geo-political zones of Nigeria. More than half of the interviewed youth were between 26 and 35 years of age. In fact, 13 youth, representing 54.2\% of the interviewees from Nigeria, were between 26 and 35 years of age. Only three respondents (12.5\%) were between 36 and 45 years. Eight of the youth, representing $33.3 \%$, were in the age bracket of 15 - 25 years.

\section{Discussion}

The destination all interviewed migrant youth had in mind was Italy, whence to proceed further into other mainland EU countries. If they could make it to the island of Lampedusa, Italy, they hoped to declare themselves refugees and asylum seekers, and then secure the means for an onward journey into mainland European countries. Some of these migrants even nursed the idea of someday leaving Europe on a more legitimate move across the North Atlantic to the Americas. After being documented, African youth migrants were incarcerated for one year and six months. Their experiences in the detention environment were described by almost all interviewees as being at best deplorable and prison-like experiences. The food they were served, the restraints, and the other living provisions were not only substandard but provided at irregular hours. They were herded out into the field in groups to receive two hours of sunshine. Each of them was allowed two hours to go outside and exercise in the sun and then rushed back into the heavily protected maximum detention house. That was a consistent condition they had to cope with for 18 months. Spending 18 months in this unhealthy state does not at the end guarantee that the migrants will secure documents from the Maltese government or the European Union to reside in Malta or any European country of their choice. In fact, some of the people interviewed disclosed that most of their colleagues were deported back to their countries shortly after detention. A male migrant youth from Nigeria pondered:

From 2006 to 2008 I was in detention before I regained my freedom. Detention was a thing you can't explain... it is like a prison also because there is no difference. The only difference is that maybe when somebody is sentenced to prison term, he would have it in mind that one day, so, so year, he will be free again. But in Malta, detention is indefinite, because you may be bundled back to your country from detention. Now I am out of detention after seventeen months. I have only one year renewable permit, which does not allow me to continue my travel to my country of choice, so we are like, stuck in Malta (Nwalutu, 2016).

Post-detention repatriation from Malta and the practice of denying the youth traveling documents are tantamount to calculated attempt to terminate migrants' goal of reaching their destination. Maria Pisani, a Maltese pro-migrant activist insists that:

Fortress Europe' has been consistent in its attempts to prevent the 'unwanted' from making their way to the mainland. The Dublin II Regulation ensures that those who manage to reach the $E U$ will remain at the periphery rather than 
make their way to the nations of Northern Europe-we are reminded that border crossing is not a choice available to all (Pisani 2012:2).

Anothermale Nigerian youth migrant from the South-South geo-political zone who participated in the interviews recounts:

But the major problem after my 18 good months in detention is that I didn't have a hope to get a resident permit. I didn't know what was going to happen the next day. I did not know if the authorities would decide to deport me back to my country of origin, Nigeria. I was very nervous about this uncertainty (Nwalutu, 2016).

Considering the recent surge in Arab refugee arrivals in Europe and the amiable attention this set of migrants are receiving from EU authorities-compassionate considerations denied most of their African counterparts-it becomes imperative to question if racism and neo-colonial antics are not the factor. In his Black Skin, White Mask, Franz Fanon (1952), uses a juxtaposition of White and Black races within the context of colonization to unveil the problems of Black identity in the milieu of Western racist and colonial repressions. Again, Fanon's (1952) work insists that blackness was projected by the colonialist West as a symbol for all negative values or instincts. Whether this mindset contributes in any way to the unwelcome treatment meted out to Nigerian migrant youth at the borders of Europe remains question.

\subsection{Anti-Colonial/Anti-Racist Lenses for Reflecting on the EU Border Restrictions against African Youth Migrants}

Colonization is an imposition of cultural, political and economic domination and hegemonic control on the subjugated individuals (Dei, 2011). Racism on the other hand is a preconceived process that derogatorily labels an individual or group for the purpose of segregation, marginalization, domination and imposition of hegemony by the dominant individual(s). It is an act of social representation and construction of difference aimed at positioning the dominant social group to enjoy certain exclusive privileges that are girded around by socio-political power imbalances and barricaded from the subordinate individual(s) with proscriptions of normativity (Fanon, 1952; Dei, 2011; Lebakeng, 2010). It is difficult to talk about neo-colonial practices and race without looking into power relationships, which is where the present neo-colonial structures and processes play critical roles. Dei (2011) and Smith (1999) reasons that anti-racists agents must move to an inclusive race-based analysis of colonial relations with the understanding that representation is not only about subject identities and identifications but also about fundamental issues of economic, material and structural manifestations in existing human conditions. Decolonization and antiracist functions therefore must aim to redress these fundamental issues. As an analytical approach anti-colonial framework is a perspective that challenges all manifestations of hegemony and imposition of ideas and practices of cultural and socio-political domination. In other words, any exercise of self-assertion or self-location is meaningful if it seeks to challenge or disrupt ex- 
isting impositions and social dynamics of power imbalances.

Relating the discourses of anti-racism to the phenomenon of African youth's experiences at the transnational borders, particularly at the extended borders of the European Union, the realities of skewed power relationship begins to emerge. The systems of border securitization and surveillance are designed to intercept and detain signifiers of racialized bodies or their representation. The taking up of such worded symbolisms as victims of traffickers, Illegal migrants, Clandestine and Boat-people are racist coinages of representation and markers of social difference at the borders of European Union. The disturbing reality of representation of difference is the positioning of the racialized individual(s) at the margins of social echelon. Therefore spaces such as transnational borders have the tendency to reproduce hegemony, dominance and privilege because such spaces also come with particular histories and readings. Therefore the experiences of the racialized bodies of African youth in European borders cannot be fully grasped in discourses of splits binaries of regular or irregular, legal and illegal migrants, because we are not unaware of the maxim that occupying certain spaces comes with meanings and politics.

The racial positioning of whiteness at international borders implies that Europe wields an unlimited power to extend its authority of border surveillance to the North African sea ports of Libya, Tunisia, Algeria, Egypt and Morocco. These ports are patrolled by FRONTEX, an EU border security agency charged with keeping the unwanted drifters out of mainland Europe (Pisani, 2012). We must avoid romanticizing the current emigration of African youth from the continent by raising the questions: how are the Sub-Saharan African youth complicit to their repressive migration experiences and untoward treatment by border authorities at the entry-ports of Europe; and how has neo-colonial structures and processes in their environments of upbringing predispose African youth to migrate? Also one would be tempted to ask what complicit role the leaders of the North African frontline states (ports of departure) are playing to make EU aggressive border policies and praxis worthwhile. These rhetoric questions are timely because of the recent observations that many young Africans have been brutally gun-down at the borders of North Africa on passage to Europe (see Brachet, 2012; Baxter, 2008; Toasije, 2009). It is sociologically a paradox of power however, that European youth traveling to Africa do not face similar harassments, criminalization, restrictions detention and deportation African youth migrants suffer at the borders of Europe. Whiteness is in essence, a system and is also a property. There is therefore a politicization of biological pigmentation at the spaces of representation. Whiteness thus becomes a pigmentary passport of privilege. To young Africans colonization and racism also brought about major severance from their geo-cultural environments (an experience Frantz Fanon referred to as amputation) of the colonized peoples first, from themselves, and then from their environment, culture and knowledge base. Fanon insists:

Perhaps we haven't sufficiently demonstrated that colonialism is not satisfied 
merely with holding a people in its grip and emptying the native's brain of all form and content. By a kind of perverted logic, it turns to the past of the oppressed people, and distorts, disfigures, and destroys it. This work of devaluing pre-colonial history takes on a dialectical significance today (Fanon, 1963: 120).

Thus alienated from their languages (WaThiong'O, 1986), knowledge of their past, and their environment (Dei, 2011; Lebakeng, 2010), and having lost touch with their identity and humanity, devoid of liberty and freedom as human beings (Fanon, 196), and completely oblivious of the basis of their humanity, that is, spirituality (Dei, 2011), the colonizer's imposed ways of knowing became reified, essentialized and taken up as the way of salvation from the supposedly "primitive" entrapment the colonized knew before the encounter. The annexation of Africa, imposition of foreign rule and cultural suppression coupled with ruthless brutality meted out on the colonized bodies, was in Fanon's view a measure of 'violence' that left significant damage on the psyche of the colonized; depriving them first of knowledge of self and identity. Then it robs them of their freedom, and liberty. To Fanon each of these tasks might require violence for decolonization is as much a "violent phenomenon" as colonization itself (Fanon, 1967: 99). It implies that the dissonance resulting from repressions experienced by young African migrants at the borders of Europe constitutes both a psychological trauma, a climax of knowing and hopefully, an apex of unrealized hope from whence a dénouement of the inequities in the global migration drama would unravel.

\subsection{Rescue, Detention, and Route Cul-De-Sac to African Youth Migrants}

David (pseudonym), a Nigerian youth migrant in Malta argues that:

It is impossible to stay in Malta forever because what I have with me is one year document, and there is the possibility the authorities here may not renew it for me. That leaves me in an impasse since I may not be permitted to continue my journey henceforth without genuine traveling documents. I am not alone, many of us from West Africa face similar ordeal. I accepted your interview offer because I am nursing the hope that your media might be a channel for bringing our predicaments to the notice of the relevant authorities (Nwalutu, 2016).

According to David, a larger percentage of the African migrant deportees were female youth, the reason being that they were unable to provide justifiable reasons for leaving their countries of birth. Others were said not to possess the requisite skills. Another interviewee, Julian (pseudonym) insists:

It was very pathetic considering all the suffering these ladies had to undergo with us right from Niger Republic through the desert all the way to Libya. Then the hurdles of the Mediterranean crossing after which we all faced 18 months of detention. It was unfair to have them deported. It was true that most of our female colleagues did not have prerequisite skills, but the government has training institutes for immigrants. They shouldn't have been sent back to go and suffer in Nigeria. I am very sorry for them. Not a single woman remained among those 
that arrived in my boat. The government of Malta deported all to Nigeria (Nwalutu, 2016).

The female youth migrants were deemed unemployable by authorities in any meaningful trade or profession. It is uncertain, though, if they were capable of learning trades and if the Maltese government was willing to provide them with such opportunities. Escape from detention was more frequent when the migrants were housed in camping tents because it was easier to plan and execute an escape. Today, a fortified detention structure transformed the idea of detention into a tough jail time. It is however a paradox that most narratives of the youth interviewees regarding their unpleasant experiences in Malta often are inconsistent with their responses to any suggestion to leave Europe and return to Africa. While recognizing that he was not treated fairly by Maltese authorities and was not accorded due recognition and respect in the Maltese society, Daniel (pseudonym) did not hesitate to interrupt when I asked his thoughts about returning to Nigeria, "that [would not] be an option at all, at all", he insists. Daniel further explains:

Because for example here in Malta when you see a police or when something is going on, everybody likes to seek the opinion of police because whenever you call the police, people know that the police, they are coming to make peace. But in Nigeria, sometimes when you are somewhere or someone is saying, "Police is coming," you take off, or maybe start running, which is not supposed to be. Now they will tell you that you committed a crime and must be bailed or risk going to jail, which is not what should ever happen (Nwalutu, 2016).

Daniel's response reaffirms the factor driving Nigerian youth to migrate in large numbers as social insecurity and hopelessness although the impact of the other factors is not to be overlooked.

Many of the youth migrants shared a mindset of reaching Italy. To this set of migrants, arrival in Malta is a stepping stone. It is a step towards realization of a lifelong dream for many of the migrants to arrive in Europe from the sea. One arrives possibly in the Italian Lampeduza Island and from there takes an onward journey to mainland EU countries. To Daniel, however, it was one thing to be in Malta or Lampedusa, Italy and another to arrive at such a time as now. The economy of European countries is not welcoming, and Italy as a nation is hard hit by recession. The impact on African youth migrants is unimaginable, and for this respondent and his colleagues who, instead of moving further from Malta into heartland Europe decided to remain in Malta after obtaining their limited permits, it was a nightmare. The European Union member states have new policies that limit the movement of migrants to their first country of entry (Pisani, 2012; Brian \& Laczko, 2014). The introduction of a border fingerprint database also means that this surveillance system is followed to its logical objectives. Once a migrant's fingerprint is taken in one of the member nations, it is recalled and subsequently used to expose and repatriate recalcitrant migrants. It works because only a few manage to dodge their ways through the complex surveillance system. And many a time those who sneaked away to other countries in the E.U. 
after documentation are caught and repatriated to their home countries. At the Ministry of Interior, Msida, Malta, a particular female respondent, Antonia (pseudonym) who arrived from Italy in search of a menial job was denied the opportunity. Without a Maltese work permit, Antonia and her colleagues may not find even the lowest paid job in Malta. They were told that since Italy was their first port of entry they should head back to Italy. Their experiences became an eye opener for the majority of the youth migrants in Malta who hoped that arrival in Malta was a landmark achievement in their doggedness to arrive in mainland Europe; because Malta and Lampeduza were to the migrants, indeed, an inextricable entanglement (Pisani, 2012).

\subsection{Vision Cut Short: Migrant's Goal at Its Waterloo (Border Restriction and Proxies)}

Securing Maltese temporary residence and/or work permits may have permanently sealed their hope of ever leaving for other parts of Europe. While regretting his arrival in Malta instead of Italy, one of the respondents reasoned-and this view was shared by many other youth migrants-that whatever obstacle or setback he has suffered were caused by the Maltese government who they claimed, reached out to them at the Sea in a charade of rescue when in reality they served to restrict them from European mainland. Another male interviewee, Samuel (pseudonym), argues that most of them who were ready to do any manner of work to survive are neither given such opportunities nor issued a work permit so they can legally secure jobs. The relevance here is not so much the connection between globalization and migration as the highlight of the link between the criminalization of migrants by the receiving states and the tough border crossing restrictions the demonized bodies must undergo, especially in Europe.

Apparently, the beginning of the 21st century saw less and less emphasis on free migration, but sovereign entities among the comity of nations (specifically the dominant industrialized North) strive very hard, to streamline what category of migrants they need, and who comes into their territories and who doesn't (Esipova, Ray, \& Srinivasan, 2011; DeLaet, 1999). Name-calling and the act of mislabeling transnational migrants by the receiving societies using mass media are noted ways of creating biases that would engender restrictive government policies against immigrants, particularly when the economic and fiscal conditions of the receiving states are unfavourable (Kretsedemas, \& Capetillo-Ponce, 2014; Kapur, 2005; Kanenko, 2003). It is no different for African youth migrating into Europe. Most of our interview participants in Malta were conversant and had resolved to live with such racist tags as Clandestine, boat-people, illegal, and Iswed (Black). The securitization of international borders also brings about the criminalization of irregular migrants, which further complicates their mobility as this category of migrants travel under a menace of being killed, repatriated, or detained. The border surveillance and restrictive strategies that expand EU 
borders beyond its territories into the imagined African land and water territories aim to regularly intercept migrants from their domestic environments of origin. This regulatory imposition of hegemonic control is an archetype of the ongoing neo-colonial power display in the relationship between the industrialized North and developing South. The disequilibria of power in the context of transnational border relations are delicately embedded in the system to evade investigation, but it is a reality.

\section{Conclusion}

Transnational borders have the tendency to reproduce hegemony, dominance, and privilege. Therefore, the experiences of the racialized bodies of African youth in European borders cannot be fully grasped in discourses of polarized features such as regular or irregular, legal and illegal migrants, nor is the infantalization of migrant bodies by projecting them as victims of traffickers any more acceptable in international border policing. This approach is simply a neo-colonial project strategy fashioned to eliminate all forms of agency from migrant bodies and blame their states of origin for thronging the border spaces of other sovereign states with their citizens. This is also a discolored version of the push-and-pull narrative. Under-valorization of migrants' agency denies their humanity, essentializes and trivializes their unique transnational border experiences, which is a colonial travesty of migrants' epistemic saliency. Furthermore, the racial positioning of whiteness at international borders implies that Europe wields an unlimited power to extend its authority of border surveillance to the North African sea ports of Libya, Tunisia, Algeria, Egypt, and Morocco. The current cooperation between the authorities of North African countries and EU that holds migrants in detention camps in Libya and other North African countries is a time bomb that will eventually adversely affect the sending and receiving states in the future. It is at best counterproductive and might only produce expected results in the short run since the root causes of youth migration in the states of origin remain unresolved. This cooperation has produced more deaths on migrants' trails to Europe as they device ways to resist onslaughts of African border authorities. Many young Africans have been killed at the borders of North Africa on passage to Europe as hinted earlier. It is ironical that Europeans traveling to Africa do not face similar harassment, criminalization, brutal attacks or detention, and deportation African youth migrants suffer at the borders of Europe. Whiteness becomes at this juncture a system and also a property. This implies that politicization of biological pigmentation happens at the EU transnational borders which hitherto continue to marginalize and racialize African youth migrants. The struggle to take up Whiteness and its accompanying privileges has proven tragic to Nigerian and by extension, African youth migrants emigrating for improved living conditions in industrialized world. Thus at the spaces of border representation, whiteness means nothing outside the tropes of neo-colonial oppression.

As a way forward, leaders of developing African countries must engage trans- 
parency in leadership, and avoid driving their youth to desperation through dishonest political practices that engender insecurity in the societies. The leaders must transform themselves into mirrors of credibility, accountability, and responsibility (that are qualities of African Indigenous leadership) for their youth to emulate. The incumbent African leadership must, as a matter of urgency, provide the basic necessities of life such as power supply, hospitals, schools and good roads. The youth must be taught and equipped to uphold such virtuous qualities as resourcefulness, resilience, and credibility, and to be responsible citizens. Nigeria and by extension other African countries might borrow a leaf from the Philippines government. In that case, Nigeria needs to establish two labor-training and exporting agencies (one for permanent and the other for temporal employment). As the receiving society EU member states may build a Buffer-City in any of the Islands or a selected unoccupied spots at the outskirts of Europe within which walls (as alternative to mainland Europe) migration surge could be contained. The government of industrialized nations must evolve measures to provide educational scholarships to foreign students, as well as cross-border recruitment of professionals and specialists for short and long term employment opportunities.

\section{References}

Baxter, J. (2008). Dust from Our Eyes: An Unblinkered Look at Africa. Hamilton: Wolsak and Wynn Publishers.

Bjarnesen, J. (2014). Refugees or Migrants? Research and Policy Analysis. Uppsala: The Nordic African Institute, Uppsala Universitet.

Brachet, J. (2012). From One Stage to the Next: Transit and Transport in (trans) Saharan Migrations. In M. Berriane, \& H. de Haas (Eds.), African Migrations Research: Innovative Methods and Methodologies. Lawrenceville, NJ: Africa World Press.

Brian, T., \& Laczko, F. (2014). Fatal Journeys: Tracking Lives Lost during Migration. IOM Report, Geneva: IOM.

Chomsky, N. (2006). Failed States: The Abuse of Power and Assault on Democracy. New York, NY: Henry Holt Books.

Chua, A. (2003). World on Fire: How Exporting Free-Market Democracy Breeds Ethnic Hatred \& Global Instability. New York, NY: Doubleday Publishing.

Davies, N. (1995). Trial of the Crew Who Murdered Stowaways. The Guardian.

Dei (2011). Introduction. In G. SefaDei (Ed.), Indigenous Philosophies and Critical Education: A Reader. New York, NY: Peter Lang.

DeLaet, D. L. (1999). Introduction: The Invisibility of Women in Scholarship of International Migration. In G. A. Kelson, \& D. L. DeLaet (Eds.), Gender and Migration. London: Macmillan Press Ltd.

Deutsche Welle (2014). IOM Releases Mediterranean Boat Migrant Counts. http://www.dw.com/en/iom-releases-mediterranean-boat-migrant-count/a-17392900

Esipova, N., Ray, J., \& Srinivasan, R. (2011). The World's Potential Migrants. Who They Are, Where They Want to Go, and Why It Matters. Gallup Organization Inc. http://www.gallup.com

Fanon, F. (1952). Black Skin, White Masks. New York, NY: Grove Press. 
Fanon, F. (1963). The Wretched of the Earth. New York, NY: Grove Press.

Frenzen, N. (2014). Shifting Responsibilities, EU FRONTEX and Migrant Rights Violation. Migrants at Sea. http://migrantsatsea.org/2014/03/24/interview-with-frontex-director-laitinen/

Heidbrink, L. (2012). At a Crossroads: Youth at the Intersection of the Family and the State. Advances in Ecopolitics, 10, 149-183. https://doi.org/10.1108/S2041-806X(2012)0000010012

Heller, C., Pezzani, L., \& Situ Studio (2012). The "Left-To-Die Boat” Forensic Oceanography Report. The European Research Council Project. London: Forensic Architecture Centre for Research Architecture, Goldsmiths, University of London.

http://www.fidh.org/IMG/pdf/fo-report.pdf

International Convention for the Safety of Life at Sea, London (1974). Entry into Force Generally: 1980. Entry into Force for Australia: 1983. Australian Treaty Series 1983, No. 22. Commonwealth of Australia: Australian Government Publishing Service Canberra.

Kanenko, M. (2003). Beyond "Seclusionist” Japan: Evaluating the Free Afghans/Refugee Law Reform Campaign after September 11. Refuge, 21.

Kapur, R. (2005). Erotic Justice: Law and the New Politics of Post Colonialism. London: Glass House Press.

Ki-mon, B. (2009). Migration through the Eyes of Young People Panel on the Occasion of International Migrants' Day. New York, NY: United Nations Institute for Training and Research (UNITAR) United Nations Headquarters.

Kretsedemas, P., \& Capetillo-Ponce, J. (2014). Introduction: The Problem of Migrant Marginality. In P. Kretsedemas, J. Capetillo-Ponce, \& G. Jacobs (Eds.), Migrant Marginality: A Transnational Perspective. New York, NY: Routledge, Taylor \& Francis Group.

Larkin, M., Watts, S., \& Clifton, E. (2006). Giving Voice and Making Sense in Interpretative Phenomenological Analysis. Qualitative Research in Psychology, No. 3, 102-120. https://doi.org/10.1191/1478088706qp062oa

Lebakeng, T. (2010). Discourse on Indigenous Knowledge Systems, Sustainable Socio-Economic Development and the Challenge of the Academy in Africa. CODESRIA Bulletin, No. 1 \& 2, 24.

Newland, K. (2003). Troubled Waters: Rescue of Asylum Seekers and Refugees at Sea. Migration Information Source. Washington DC: Migration Policy Institute. http://www.migrationpolicy.org/article/troubled-waters-rescue-asylum-seekers-and-ref ugees-sea

Nwalutu, M. O. (2014). Youth and the 21st Century South-North Migration: In Search of a More Relevant Perspective on Causes, Trend and Flow. Sociology Mind, 1, 1-14. https://doi.org/10.4236/sm.2014.41001

Nwalutu, M. O. (2016). From Africa to Europe, Youth and Transnational Migration: Examining the Lived Experiences of Nigerian Migrant Youth in Malta. PhD Thesis, Toronto: ProQuest/Uof T Library Repository.

https://tspace.library.utoronto.ca/browse?type=title\&sort_by=1\&order=ASC\&rpp=20\& etal=-1\&starts_with=from + Africa+to+Europe

Phillips, M. (2014). Guest Post: The Effect of Negative Labelling-Why Are We Still Talking about "Migrants"? Migrants at Sea.

http://migrantsatsea.org/2014/07/01/guest-post-the-effect-of-negative-labelling-why-ar e-we-still-talking-about-migrants/ 
Pisani, M. (2012). Lifelong Learning and Inclusion: The "Citizenship Assumption" and the Exclusion of 8 Million Bodies. In 44th EUCEN November Conference Border-Crossing as a Viable Choice: Collaboration, Dialogue and Access to Higher Education.

Sassen, S. (2003). Global Cities and Survival Circuits. In B. Ehrenreich, \& A. R. Hochschild (Eds.), Global woman: Nannies, Maids and Sex Workers in the New Economy. London: Granta Books.

Shea, A. (2012). Perilous Territory: Non-Status People in Canada. Oxford Monitor of Forced Migration, 1, 91-105.

http://oxmofm.com/wp-content/uploads/2012/06/Perilous-Territory.pdf

Simms, A. (2009). Ecological Debt: Global Warming \& the Wealth of Nations. New York, NY: Pluto Press.

Smith, J. A., \& Osborn, M. (2007). Pain as an Assault on the Self: An Interpretative Phenomenological Analysis. Psychology and Health, No. 22, 517-534. https://doi.org/10.1080/14768320600941756

Smith, L. (1999). Decolonizing Methodologies: Research and Indigenous Peoples. London: Zed Books Ltd.

Strik, T. (2012). Lives Lost in the Mediterranean Sea: Who Is Responsible? Report, Committee on Migration, Refugees and Displaced Persons Netherlands, Socialist Group, Council of Europe.

http://assembly.coe.int/committeedocs/2012/20120329_mig_rpt.en.pdf

Sunderland, J. (2012). Hidden Emergency: Migrants Death in the Mediterranean. Human Rights in Europe. New York, NY: Human Rights Watch. http://www.hrw.org/sites/default/files/related_material/2012_EU_Hidden\%20Emergen cy.pdf

Toasije, A. (2009). The Africanity of Spain: Identity and Problematization. Journal of Black Studies, 39, 348-355.

WaThiong'O, N. (1986). Decolonizing the Mind: The Politics of Language in African Literature. Nairobi: East African Educational Publishers.

Willinsky, J. (1998). Learning to Divide the World: Education at Empire's End. Minneapolis, MN: University of Minnesota Press.

Wong, S. (2009). Migration through the Eyes of Young People Panel on the Occasion of International Migrants' Day. New York, NY: United Nations Institute for Training and Research (UNITAR), United Nations Headquarters. 


\section{Appendix}

The preliminary questions to research included the following enquiries:

\begin{tabular}{|c|c|c|c|c|}
\hline$S / N$ & Research questions & Objective of the questions & Participants & Data \\
\hline 01 & $\begin{array}{l}\text { How might we define transnational youth } \\
\text { migration? }\end{array}$ & $\begin{array}{l}\text { Get the definition of transnational } \\
\text { migration of youth. }\end{array}$ & Nigerian youth & $\begin{array}{c}\text { Youth of European } \\
\text { descent }\end{array}$ \\
\hline 02 & $\begin{array}{l}\text { What socio-political or economic factors influence } \\
\text { youth decision to migrate? }\end{array}$ & $\begin{array}{l}\text { Establish factors influencing youth } \\
\text { migration }\end{array}$ & $\begin{array}{c}\text { Nigerian } \\
\text { youth migrants }\end{array}$ & $\begin{array}{c}\text { European migrant } \\
\text { youth }\end{array}$ \\
\hline 03 & $\begin{array}{l}\text { How and what legal barriers did youth migrants } \\
\text { encounter at the Malta port of entry? }\end{array}$ & $\begin{array}{l}\text { Identify elements of border surveillance } \\
\text { and social interrogation. }\end{array}$ & $\begin{array}{l}\text { Nigerian migrant } \\
\text { youth/European } \\
\text { migrant youth }\end{array}$ & $\begin{array}{l}\text { structured } \\
\text { interview }\end{array}$ \\
\hline 04 & $\begin{array}{l}\text { What perceptions of Nigerian immigrant youth do } \\
\text { Maltese hold against their continued settling in } \\
\text { Malta? }\end{array}$ & $\begin{array}{l}\text { Find out the opinions of Maltese against } \\
\text { Nigerian immigrant youth. }\end{array}$ & $\begin{array}{c}\text { Nigerian } \\
\text { migrant youth }\end{array}$ & $\begin{array}{l}\text { Unstructured } \\
\text { interview }\end{array}$ \\
\hline 05 & $\begin{array}{l}\text { How do Maltese perceive non-citizens living } \\
\text { among them? }\end{array}$ & $\begin{array}{l}\text { Find out the opinions of Maltese on } \\
\text { immigrants generally. This shapes } \\
\text { public opinion and immigration policies }\end{array}$ & $\begin{array}{l}\text { Nigerian migrant } \\
\text { youth/European } \\
\text { migrant youth }\end{array}$ & $\begin{array}{l}\text { Structured } \\
\text { interview }\end{array}$ \\
\hline 06 & $\begin{array}{l}\text { What are the attitudes of Maltese authorities } \\
\text { (immigration personnel and police) to immigrant } \\
\text { youth? }\end{array}$ & $\begin{array}{l}\text { Understanding how Maltese } \\
\text { authorities react to discourage or } \\
\text { encourage immigrants youths to settle in } \\
\text { Malta }\end{array}$ & $\begin{array}{l}\text { Migrant Nigerian } \\
\text { youth/European } \\
\text { migrant youth }\end{array}$ & $\begin{array}{l}\text { Structured } \\
\text { interview }\end{array}$ \\
\hline 07 & $\begin{array}{l}\text { What are the economic, social and political } \\
\text { constraints faced by immigrant youth in settling in } \\
\text { Malta? }\end{array}$ & $\begin{array}{l}\text { Find out the structures of repression } \\
\text { constraining migrant youth in host } \\
\text { nations. }\end{array}$ & $\begin{array}{l}\text { Nigerian migrant } \\
\text { youth/European } \\
\text { migrant youth }\end{array}$ & $\begin{array}{l}\text { Unstructured } \\
\text { interview }\end{array}$ \\
\hline 08 & $\begin{array}{l}\text { What efforts do immigrant youth apply to navigate } \\
\text { around perceived barriers posed by social, political } \\
\text { and economic systems in Malta, such as accessing } \\
\text { resources? }\end{array}$ & $\begin{array}{l}\text { This question seeks to establish how } \\
\text { migrant youth resist subjugation and the } \\
\text { skill they use to re-establish their } \\
\text { humanity and survival. }\end{array}$ & $\begin{array}{l}\text { Nigerian migrant } \\
\text { youth/European } \\
\text { migrant youth }\end{array}$ & $\begin{array}{l}\text { Structured } \\
\text { interview }\end{array}$ \\
\hline 09 & $\begin{array}{l}\text { How does Western education equip migrants to } \\
\text { survive in Malta socio-economic spaces? }\end{array}$ & $\begin{array}{l}\text { Find out how Western (colonial) } \\
\text { education acquired in Nigeria equip } \\
\text { Nigerian migrant youth to find } \\
\text { employment in Malta. }\end{array}$ & $\begin{array}{l}\text { Nigerian migrant } \\
\text { youth }\end{array}$ & $\begin{array}{c}\text { European } \\
\text { Migrant youth }\end{array}$ \\
\hline 10 & $\begin{array}{l}\text { Given every opportunity, would migrant youth } \\
\text { prefer to return to their countries of origin? }\end{array}$ & $\begin{array}{l}\text { Find out if migrant youth are in deadlock } \\
\text { and would prefer to return home or } \\
\text { continue to stay in Malta. }\end{array}$ & $\begin{array}{l}\text { Nigerian migrant } \\
\text { youth/European } \\
\text { migrant youth }\end{array}$ & $\begin{array}{l}\text { Unstructured } \\
\text { interview }\end{array}$ \\
\hline
\end{tabular}

